\title{
Comparative Study of Globalism Amount of High School Teachers and Students in Semnan City: Evidence from Iran
}

\author{
Bokharaei Ahmad $^{1}$, Bagheri Marzieh ${ }^{2} \&$ Hoseini Marzieh Sadat $^{2}$ \\ ${ }^{1}$ Faculty member of Social Sciences Department, Payamnoor University, Tehran, Iran \\ ${ }^{2}$ Payamnoor University, Tehran, Iran \\ Correspondence: Bokharaei Ahmad, Faculty member of Social Sciences, Payamnoor University, Tehran, Iran. \\ E-mail: bokharaei_ah@yahoo.com
}

Received: May 10, 2015 Accepted: October 19, 2015 Online Published: October 28, 2015
$\begin{aligned} & \text { doi:10.5539/ass.v11n25p179 } \\ & \text { URL: http://dx.doi.org/10.5539/ass.v11n25p179 }\end{aligned}$

\begin{abstract}
Globalism is a basic phenomenon that impresses not only economic, social, and industrial aspects of human life but also has revolved educational, cultural, and religious lives of different people across the globe. This study aims at the comparative study of globalism amount of high school teachers and students regarding social, cultural, political, and economic dimensions. In this study, the factors of gender, residence place and level, social and economic status, education level, and access to new media like satellite and Internet have been considered as effective factors in globalism amount of teachers and students. Hypotheses were tested using survey approach. Statistical population included all high school teachers and students in Semnan City (Iran) in school year of 2013-2014. Using simple random sampling, the sample size of 490 (190 teachers and 300 students) was achieved. To gather data, a researcher-made questionnaire was used. Results showed that students have higher globalism tendency compared with their teachers that is statistically significant as well. Finally, pathologically, globalism difference of students with teachers leads to emotional, cultural, and ideological gaps between teachers and students which and can be identified as a big cultural alarm in the society.
\end{abstract}

Keywords: attitude, globalism, Iran, media, student, teacher

\section{Introduction}

At the moment, effective factors in children's growth are not limited to the family and society; but, they are affected by global events and personalities. Then, value system of our children is impressed by the dominant global culture. Nowadays, social and behavioral dangers and damages of new media exceed its other damages. The phenomenon of globalism is inevitable and removes all geographical borders. It affects not only cultural aspects deeply, creating global identity and culture, but also revolves political, social, and economic aspects of people's daily lives. New media such as satellite and Internet can spread this phenomenon greatly for their high penetration and effectiveness among the people (Golmohammadi, 2003). Despite the beliefs of previous decades, among a vast group of teachers and students who spend their break time using global media, especially, in the conditions which high school students are involved with additional classes and tests, educational progress, entrance exams, and gaining acceptable scores and while teachers hold extra classes and have secondary jobs for wining bread, not gaining a chance to get necessary trainings about global issues is concerning.

Globalism is not dangerous and has positive aspects such as revolving the relationships between big urban centers and places nearby. The interaction of organizations, groups, and institutes in the cities that create strong bonds for them leads to a group common factor that can be effective in the political, economic, and cultural areas (Giddens, 86).

This study aims at a comparative study of globalism amount of high school teachers and students, measuring their attitudes towards new communication media. The aim is answering the questions as follows: How much globalism is there in the teachers and students? How effective are new communication media in the attitudes and globalism amount of the students and teachers? How effective is this difference in the process of mutual educational action in the class and school?

Familiarity with globalism trends especially in education system and high schools can provide necessary grounds for accepting or not accepting this phenomenon. Also, regarding generation difference among the teachers and 
students, attitude type and acceptance of these two groups may be different. Accordingly, comparing globalism amount of the students and teachers regarding its four dimensions, these questions were examined in this study.

\section{Background}

For the importance of globalism and the role and effect of new mass media on it, there have been different researches inside and outside the country.

Results of Edrisi (2007) titled "Effective factors in youth attitudes towards global culture" in second school year of 2005 -2006 at three levels of BA, MA, and Ph.D showed that attitudes towards global culture has maximum correlation with education level of the subjects. Findings showed that attitudes towards global culture have a significant correlation with personal features, family features, and satisfaction from the country. Study of Shahnooshi and Lelari titled "Effective factors in youth attitudes towards globalism culture in Islamic Azad University of Shooshtar" showed that variables of (internal and external) reference groups, cultural attitude of the family, attitude of friends' group towards the relationship with western world and satisfaction from the country affect youth attitudes towards globalism (Shahnooshi \& Lelari, 2010).

In their study titled "Examining the attitude of high school students towards globalism and its effects on national and religious values and identity of them", Lotfabadi and Noroozi (2005) showed that active attitude in pre-university students is higher while the passive attitude towards globalism is lower in them. Study of Inglehart (2000) showed the occurance of enormous changes in the beliefs of the people for globalism invasion. This study showed a systematic revolution in the beliefs of the people and the reflection of economic changes, industrial achievements, and industrial technologies and the role of dominant media in the spread of economic, social, and cultural values for globalism.

In their study, Stromquist and Monkman (2000) introduced globalism as a phenomenon which affects all aspects of cultural life such as gender, attitude (feminism amd musculinism), knowledge, formal training, higher education, women's studies, adults' training, identity, and life style of the people. Changes that globalism create in economic, social, political, and cultural life of the people affect education (teachers and students) and its elements deeply (Stromquist \& Monkman, 2000; cited in Lotfabadi \& Noroozi, 2004).

\section{Theoretical Framework}

Globalism is a concept in social sciences with several definitions. Generally, globalism is a movement towards a united society in which restrictions on social and cultural relations are removed. In this way, only one society, culture, and civilization and in one word a compact world is formed on the earth (Bayat, 2007).

Robertson suggests that in globalism universal density, increase of awareness about the world as a whole, mutual dependence in the world, and awareness about global unity in twentieth century occurs (Afroogh, 2008). In such a society, communication among the people who live far from each other is as easy as the relations with neighbours. Despite all definitions, the feature of increasing communication with others and effectiveness in decision-making of other societies in introducing globalism is undeniable. Thus, along with globalization, the degree of effectiveness of internal economy, indigenous culture, and national authority is higher than external factors. Societies can be more effective proportional to their active presence in global areas, depending on the way of positioning, power, skills and activities they have (Nahavandian, 2004).

Definition of Giddens from globalism identifies the role and effect of foreign factors on domestic affairs of countries in globalism. He states that improving global social events which relates far places in a way that any event is affected by the event which is miles away from it and visa versa (Giddens, 1998). The most perfect stage of globalism can be the complete reconstruction of social relations in the world and the bonds of the person and society in such an area. In such conditions, no local and even personal area can preserve its independence and privacy and even the furthest places can be impressed by global events.

Undoubtedly, one consequence of globalism is creating a gap between two generations one of which has deeper roots in tradition.

Nowadays, with the spread of mass media, the duty of culture transfer is on them and the trend of culture spread is without any barrier.

When the identity of two generations doesn't have a constructive and improving shape, generation conflict occurs. Generation conflict manifests in cultural arenas and social trends of two generations. Generation conflict leads to generation cessation in case of severity. Generation cessation is the consequence of cultural cessation (Bokharaei, 2007).

Cultural cessation is the product of a big distance and deep cultural gap. Such gap is seen among cultural elements, 
material and immaterial aspects. If globalism trend does not occur between two generations harmonically, a break occurs which can be harmful. Generation gap is along with anonymity. In case of its occurrence, the person feels that he/she is culturally abandoned. From then, social diversion starts. People who feel failed in the transfer of culture may resort to norm-breaking activities. Here, globalism is a process which includes different aspects such as political, cultural, economic, and social dimensions (Bayat, 2007).

Political aspect of globalism is the decrease of government-nation's role and the increase of the role and power of companies and international organizations. In global politics, national governments lose their control, management, and authority and their supervision over internal forces decreases. The agents of fulfilling globalism in politics are the governments which accept to weaken themselves internally through willingly joining to the networks and international organizations especially global business organization, increasing the dominance of central countries over themselves (Afroogh, 2008).

Globalism of economy accompanies privatization, business liberalization, removing rules in the business, reducing taxes, minimizing public supervision, fast growth of multinational companies, spread of global financial centers, workers' immigration, revolution in transportation and communication network, and dependence of economic value to information business and not material business (Hejazi, 2003).

Cultural globalism refers to the formation and spread of a specific culture in the global area. This process creates a wave of cultural homogeneity in the world, challenging all cultural specifications. Globalism creates an international economy in economics and an international society in politics, forming a global culture. Cultural globalism that includes a kind of cultural sameness circulates a globalized consumption culture through global media. Nowadays, that culture will be western regarding scientific, technological, and technical superiorities which exist in the west and in this way, indices and values of western modernity are exported to the whole world (Golmohammadi, 2003).

Social globalism affects families very fast. Changes in the pattern and lifestyles, roles and relations in the family have led to marriage decrease, divorce increase, personal and social dissatisfaction, increase of value conflicts inside the family, increase of internal and external immigrations, and urbanism. These factors affect distorting social order and balance especially in developing societies (Sahabi \& Aghabeikpouri, 2010).

Fast spread of migrations and tourism, globalism of life patterns, and common global issues are the signs of social globalism (Bayat, 2007).

Before fulfilling globalism indices, attitudes towards this phenomenon in the society are important. Attitude is not an ambiguous type of the mood or feelings but is a form of experience that 1) is related to specific objectivities, events, people, or issues, and 2) is basically evaluative. From the other hand, an attitude is not a good or bad feeling but is based on what is really good or bad or else (Esier \& Pligt, 1988).

As a classic theoretician of attitude, Alport describes it as follows" attitude is a mental state resulting from a willingness that is organized via experience and has an oriented and dynamic effect on the personal responses to all issues and situations in relation with it (Alport \& Jones, 1992). Since this study is for measuring attitude and globalism amount of the subjects, for the theoretical background of the study, theory of social structure's role in the people's attitude was selected. This approach was suggested by Kiecolt. Studying the literature of the relationship between social structure and attitude; he concludes that the factors of social structure especially social-economic role and status have main effects in forming people's attitudes in the society. Examining the works of Marx, Thomas, and Znaniecki, Kiecolt (1988) states that social and cultural structures in the society affect tendencies of the people in the society directly or indirectly. In his belief, social changes, roles, role transfer, background vocational features and social context, economic and social status, and mass media and etc. impress personal and social attitudes. However, he accepts a bilateral correlation between social structure and attitude, believing that attitudes of the people towards themselves, society, and their relations with the society are important social phenomena with real results that affect social structure. Based on this theory, social structure affects people's attitude through mediating variables such as personal penetration, social communication, organizational backgrounds, social networks, social microstructures, group media, and etc. In the final analysis, Kiecolt finds that psychological processes in the heart of primary and smaller groups play an important role in affecting social structure and the people's attitude. By psychological processes, he means the capability of interpretation and evaluation of people's experience by themselves (Kiecolt, 1988). The issue of globalism, adopted from Bayat's classification (2007), is divided into cultural dimension (Giddens, 1999; Linson, 1999; Golmohammadi, 2003), social dimension (Bayat, 2007, Sahabi \& Aghabeygpouri, 2010), political dimension (Afroogh, 2008) and economic dimension (Vioyorka, 2002; Hejazi, 2003). Factors such as gender, residence place and level, social status, and using new media (satellite and Internet) have been regarded as background 
factors in people's attitude towards globalism which affect people's globalism in cultural, social, economic, and political dimensions. Thus, the attitudes of both groups (teachers and students) towards globalism were measured and the relationship of some background factors with globalism of teachers and students was measured.

\section{Hypotheses}

\subsection{Main Hypothesis}

There is a significant difference between globalism amount of teachers and students.

\subsection{Alternative Hypothesis}

1. There is a significant difference between globalism of teachers and students in cultural dimension.

2. There is a significant difference between globalism of teachers and students in social dimension.

3. There is a significant difference between globalism of teachers and students in political dimension.

4. There is a significant difference between globalism of teachers and students in economic dimension.

5. There is a significant correlation between social-economic status of the teachers and their globalism.

6. There is a significant correlation between social-economic status of the students' parents and students' globalism.

7. There is a significant correlation between residence place and subjects' globalism.

8. There is a significant correlation between using new media and subjects' globalism.

\section{Methodology}

This study uses survey approach. To gather data, a researcher-made questionnaire was used which was filled by presence. Using Cochran formula and random sampling method, the sample size of 490, including 300 students and 190 teachers of Semnan City (Iran) in school year of 2013-2014 was achieved. Going to 10 public high schools ( 5 feminine high schools and 5 masculine high schools), 190 teachers were selected by simple random sampling and 300 students were selected using systematic random sampling based on the number of teachers' notebooks and the questionnaires were distributed. It included general questions (10 questions) including sex, residence place and level, education level and parents' job, education level of teachers, access and using new media (satellite and Internet); and expertism questions (32 questions) including tendency to cultural dimension of globalism(9 questions), tendency to social dimension of globalism(10 questions), tendency to political dimension of globalism (7 questions), and tendency to economic dimension of globalism (6 questions) measured in 5-point likert scale. Consistency of the questionnaire using Cronbach Alpha for all variables is achieved to be 0.76 (Table 1). Since all values are above 0.7 , all questions have acceptable consistency.

Table 1. Results of consistency test for research variables

\begin{tabular}{lll}
\hline Variables & Questions No & Cronbach Alpha \\
\hline Globalization & 32 question & 0.76 \\
Cultural dimension & 9 question & 0.73 \\
Social dimension & 10 question & 0.77 \\
Political dimension & 7 question & 0.76 \\
Economic dimension & 6 question & 0.81 \\
\hline
\end{tabular}

\subsection{Dependent Variable}

According to Oveisi and Bakhshi (2003), cultural dimension of globalism refers to formalizing one's nationality and culture, attention to consumption habits, growth and development of the culture and respect to other cultures, attention and respect to different religions, avoidance from thinking absolute about one's own culture besides preserving national identity, familiarity with abilities and restrictions of one's and others' culture, belief in the lack of restriction in using new media (satellite and Internet) such as bans, parasites, filter, and etc., creating a good context for spreading scientific and research spirit among the students and teachers, attention to different views, attitudes, and beliefs. According to Sahabi and Aghabeikpouri (2010), social dimension of globalism refers to the ability of understanding, accepting, and tolerance of cultural differences, self-reliance spirit, self-guidance, self-esteem, and tendency to acceptance and playing social roles, stimulating respect feeling at national and global levels, attention and emphasis on life skills, creating ability in the students towards accepting social responsibility, 
having a useful and effective relation with others, attention to order and importance of being knowledgeable, tendency to life changes and consumption habits for preserving environment, empathy, sympathy, assistance, and growth of language skills.

Based on Oveisi and Bakhshi (2003), political dimension of globalism refers to attention to developing international communication, international organizations, different civilizations, nations' talks, stress on daily issues at regional, national, and global level, creating sensitivity towards political events at regional and global level, familiarity with the causes and consequences of power inequality, teaching scientific identification of political events, and improving thinking skills, judgment, comments, and decision-making in this field, creating hopefulness spirit, self-confidence, and necessity of changes against globalization, training global citizens, offering necessary information and proper attitudes towards global approaches, and law-centrism.

According to Pishgahifard (2001), economic dimension refers to the existence of different markets in different places, freedom and spread of economic transactions, common investments, revolution in IT technology, transportation, international work division, importance of transaction among people, attention to restricted resources, and economizing the resources, optimum usage of resources, existence of different economic organizations at national and global level, and economic ability with the improvement of economic cooperation.

\subsection{Independent Variables}

In this study, social and economic status of teachers is measured with their income and education level and social and economic status of students' parents is gauged by jobs, income, and education level of them.

New media is another independent variable. It measures the amount of teachers and students' usage from new media (satellite and Internet) in 5-point likert scale. Third independent variable, educational generation refers to the students' parents and teachers' academic studies.

\section{Results and Discussion}

Descriptive data are shown in the following tables. Demographic findings of the study are shown in Table 2.

Table 2. Proportional distribution of respondents based on gender

\begin{tabular}{lll}
\hline Respondents & Gender & female \\
\hline Teachers & male & $51 \%$ \\
students & $49 \%$ & $53 \%$ \\
\hline
\end{tabular}

Table 3. Proportional distribution of respondents based on education level

\begin{tabular}{lllllll}
\hline \multirow{2}{*}{ Respondents } & \multicolumn{2}{l}{ Education } & & & \\
& MA & 3rd grade & BA & 2nd grade & Associate degree & 1st grade \\
\hline $\begin{array}{l}\text { Teachers } \\
\text { students }\end{array}$ & $25 \%$ & & $67 \%$ & & $8 \%$ & $30 \%$ \\
\hline
\end{tabular}

Table 4. Proportional distribution of respondents based on parents' job

\begin{tabular}{lllllll}
\hline Respondents & $\begin{array}{l}\text { Job } \\
\text { other }\end{array}$ & shopkeeper & farmer & employee & unemployed & worker \\
\hline Teachers & $20 \%$ & $25 \%$ & $21 \%$ & $8 \%$ & $13 \%$ & $3 \%$ \\
students & $21 \%$ & $17 \%$ & $15 \%$ & $21 \%$ & $9 \%$ & $17 \%$ \\
\hline
\end{tabular}

Table 5. Proportional distribution of respondents based on parents' education level

\begin{tabular}{lllll}
\hline \multirow{2}{*}{ Respondents } & Education & & & \\
& BA and higher & diploma & Under diploma & illitrate \\
\hline Teachers & $7 \%$ & $13 \%$ & $60 \%$ & $20 \%$ \\
students & $16 \%$ & $15 \%$ & $50 \%$ & $19 \%$ \\
\hline
\end{tabular}


Table 6. Proportional distribution of respondents based on residence place and level

\begin{tabular}{llllll}
\hline \multirow{2}{*}{ respondents } & \multicolumn{2}{l}{$\begin{array}{l}\text { Education } \\
\text { Residence level }\end{array}$} & \multicolumn{2}{l}{ Residence place } \\
& towns & suburb & City center & village & city \\
\hline Teachers & $23 \%$ & $25 \%$ & $52 \%$ & $6 \%$ & $94 \%$ \\
students & $17 \%$ & $30 \%$ & $53 \%$ & $15 \%$ & $85 \%$ \\
\hline
\end{tabular}

Table 7. Proportional distribution of respondents based on family income

\begin{tabular}{lllll}
\hline \multirow{2}{*}{ respondents } & $\begin{array}{l}\text { Income } \\
\text { Over 20 million (rials) }\end{array}$ & $10-20$ million rials & $5-10$ million rials & Below 5 milliom rials \\
\hline Teachers & $16 \%$ & $45 \%$ & $39 \%$ & 0 \\
students & $19 \%$ & $20 \%$ & $43 \%$ & $18 \%$ \\
\hline
\end{tabular}

Table 8. Proportional distribution of respondents based on using new media

\begin{tabular}{lllllllllll}
\hline & \multicolumn{3}{l}{ Teachers (190) } & \multicolumn{1}{c}{ Students $(300)$} \\
Variables & $\begin{array}{l}\text { Over } \\
4 \mathrm{~h}\end{array}$ & $2-4 \mathrm{~h}$ & $1-2 \mathrm{~h}$ & $\begin{array}{l}\text { Below } \\
\mathrm{lh}\end{array}$ & inaccess & $\begin{array}{l}\text { Over } \\
4 \mathrm{~h}\end{array}$ & $2-4 \mathrm{~h}$ & $1-2 \mathrm{~h}$ & $\begin{array}{l}\text { Below } \\
1 \mathrm{~h}\end{array}$ & inaccess \\
\hline $\begin{array}{l}\text { Internet usage per } \\
\text { day }\end{array}$ & $21 \%$ & $42 \%$ & $24 \%$ & $13 \%$ & $10 \%$ & $24 \%$ & $41 \%$ & $25 \%$ & $5 \%$ & $5 \%$ \\
$\begin{array}{l}\text { Satellite usage per } \\
\text { day }\end{array}$ & $29 \%$ & $21 \%$ & $17 \%$ & $14 \%$ & $19 \%$ & $30 \%$ & $33 \%$ & $18 \%$ & $5 \%$ & $14 \%$ \\
\hline
\end{tabular}

As seen in Table $8,24 \%$ of teachers and $21 \%$ of the students don't have access to Internet. This inaccessibility is for that many students were from the villages around the city and didn't have Internet. It means that if they had more access, their globalism could be higher. Generally, $35 \%$ of the teachers and $47 \%$ of the students use Internet over $1 \mathrm{~h}$ a day. In Table $8,30 \%$ of the teachers and $29 \%$ of students declared not having satellite. In access of students to satellite was for having traditional structure in rural houses and disagreement of parents with it. $37 \%$ of teachers and $50 \%$ of the students use satellite programs over $1 \mathrm{~h}$ a day. This shows that the amount of using Internet and satellite in a day among the students is higher than the teachers. Table 9 comares the amount of teachers and students globalism regarding its dimensions.

Table 9. Comparing globalism amount of teachers and students regarding its dimensions

\begin{tabular}{llllllll}
\hline $\begin{array}{l}\text { Globalism } \\
\text { educational generation }\end{array}$ & $\begin{array}{l}\text { Economic } \\
\text { mean }\end{array}$ & $\begin{array}{l}\text { Political } \\
\text { mean }\end{array}$ & $\begin{array}{l}\text { Social } \\
\text { mean }\end{array}$ & $\begin{array}{l}\text { Cultural } \\
\text { mean }\end{array}$ & $\begin{array}{l}\text { Globalism in all } \\
\text { aspects mean }\end{array}$ & $\begin{array}{l}\text { Basic } \\
\text { mean }\end{array}$ \\
\hline Teachers & 3.43 & 3.45 & 2.87 & 3.24 & 3.22 & \\
Students & 3.69 & 3.91 & 3.64 & 3.79 & 3.82 & 3 \\
Mean difference & 0.46 & 0.46 & 0.23 & 0.55 & 0.30 & \\
\hline
\end{tabular}

Table 9 shows that students have higher globalism than teachers $(0.60)$. Comparing students and teachers in other aspects of globalism shows that both groups have higher globalism in economic and political aspects. This issue can result from the conditions of recession and inflation in Iran. The mean score of 3 among teachers and students shows average globalism.

Table 10. Results of t-test for comparing cultural globalism in teachers and students

\begin{tabular}{lllllllllll}
\hline index & groups & no & mean & sd & Mean difference & t & min & max & df & $\operatorname{Sig}(\mathrm{p})$ \\
\hline \multirow{2}{*}{ globalism } & Teacher & 190 & 32.25 & 5.11 & 7.04 & \multirow{2}{*}{14.21} & \multirow{2}{*}{9} & \multirow{2}{*}{45} & \multirow{2}{*}{488} & 0.000 \\
& student & 300 & 39.21 & 5.42 & & & & & & \\
\hline
\end{tabular}


As seen in Table 10, the mean of cultural globalism in teachers is 32.25 and it is 39.21 in students. Regarding calculated $t(14.21)$ and significance level $(\alpha=0.000)$ of it, this difference is statistically significant. Thus, at $99 \%$ confidence level, mean difference of cultural globalism in two groups is statistically significant and $\mathrm{H} 1$ is confirmed. Therefore, students are more exposed to cultural globalism than teachers. So, they like to think about cultural interactions and act globally.

Table 11. T-test results for comparing social globalism in teachers and students

\begin{tabular}{lllllllllll}
\hline index & group & no & mean & sd & Mean difference & t & min & max & df & $\operatorname{Sig}(\mathrm{p})$ \\
\hline \multirow{2}{*}{ globalism } & Teacher & 190 & 29.31 & 3.21 & \multirow{2}{*}{9.32} & 12.52 & 5 & 50 & \multirow{2}{*}{488} & 0.000 \\
& student & 300 & 38.63 & 5.76 & & & & & & \\
\hline
\end{tabular}

As seen in Table 11, the mean of social globalism in teachers is 29.31 and it is 38.63 in students. Regarding calculated t $(12.52)$ and significance level $(\alpha=0.000)$, this difference is statistically significant. Thus, at $99 \%$ confidence level, mean difference of cultural globalism in two groups is statistically significant and $\mathrm{H} 2$ is confirmed. Therefore, students are more exposed to social globalism than teachers. So, they like to think about social interactions and act globally.

Table 12. T-test results for comparing political globalism in teachers and students

\begin{tabular}{lllllllllll}
\hline index & groups & no & mean & sd & Mean difference & $\mathrm{t}$ & $\min$ & $\max$ & $\mathrm{df}$ & $\mathrm{Sig}(\mathrm{p})$ \\
\hline \multirow{2}{*}{ globalism } & Teacher & 190 & 24.95 & 3.43 & \multirow{2}{*}{6.72} & \multirow{2}{*}{10.54} & 7 & \multirow{2}{*}{35} & \multirow{2}{*}{488} & 0.000 \\
& student & 300 & 31.67 & 5.98 & & & & & & \\
\hline
\end{tabular}

As seen in Table 12, the mean of political globalism in teachers is 24.95 and it is 31.67 in students. Regarding calculated t (10.54) and significance level $(\alpha=0.000)$, this difference is statistically significant. Thus, at $99 \%$ confidence level, mean difference of political globalism in two groups is statistically significant and H3 is confirmed. Therefore, students are more exposed to political globalism than teachers. So, they like to think about political interactions and act globally.

Table 13. T-test results for comparing economic globalism in teachers and students

\begin{tabular}{lllllllllll}
\hline index & group & no & mean & sd & Mean difference & t & min & max & df & Sig(p) \\
\hline \multirow{2}{*}{ globalism } & Teacher & 190 & 25.65 & 3.6 & 2.78 & 9.11 & \multirow{2}{*}{6} & \multirow{2}{*}{30} & \multirow{2}{*}{488} & 0.000 \\
& student & 300 & 27.43 & 4.9 & & & & & & \\
\hline
\end{tabular}

Table 14. t-test results for comparing globalism in teachers and students

\begin{tabular}{lllllllllll}
\hline index & groups & no & mean & sd & Mean difference & t & min & max & df & Sig(p) \\
\hline \multirow{2}{*}{ globalism } & Teacher & 190 & 110.31 & 11.43 & \multirow{2}{*}{30.26} & \multirow{2}{*}{10.54} & \multirow{2}{*}{32} & \multirow{2}{*}{160} & \multirow{2}{*}{488} & 0.000 \\
& student & 300 & 140.57 & 13.36 & & & & & & \\
\hline
\end{tabular}

As seen in Table 13, the mean of economic globalism in teachers is 25.65 and it is 27.43 in students. Regarding calculated t (9.11) and significance level $(\alpha=0.000)$, this difference is statistically significant. Thus, at $99 \%$ confidence level, mean difference of political globalism in two groups is statistically significant and $\mathrm{H} 4$ is confirmed. Therefore, students are more exposed to economic globalism than teachers. So, they like to think about economic interactions and act globally.

As seen in Table 14, regarding t value (10.54) and significance level $(\alpha=0.024)$, the mean difference is statistically significant. Thus, at $95 \%$ confidence level, it is said that mean difference of globalism in two groups is statistically significant.

Results of Table 15 shows that regarding the result of Spearmen correlation test $(r=-0.39)$ and significance level $(\alpha=0.04)$, at $95 \%$ confidence level and error level below 0.05 , it is said that the correlation between the 
social-economic status of teachers and globalism is positive. In other words, any variation (increase or decrease) in one variable leads to the variation of the other. It means that the higher social-economic status of teachers (i.e. education and income), the higher the globalism of teachers. Thus, H5 is confirmed.

Table 15. Results of correlation test for the social-economic status of teachers and globalism

\begin{tabular}{|c|c|c|c|c|c|}
\hline Variables & $\begin{array}{l}\text { Measure of } \\
\text { variables }\end{array}$ & $\begin{array}{l}\text { Correlation } \\
\text { type }\end{array}$ & statistics & $\begin{array}{l}\text { Correlation } \\
\text { value }\end{array}$ & sig \\
\hline $\begin{array}{l}\text { social-economic status of teachers - } \\
\text { globalism }\end{array}$ & $\begin{array}{l}\text { Sequential- } \\
\text { sequential }\end{array}$ & Spearman & $\mathrm{r}$ & 0.39 & 0.04 \\
\hline
\end{tabular}

Table 16. Results of correlation test for social-economic status of students and globalism

\begin{tabular}{|c|c|c|c|c|c|}
\hline variables & $\begin{array}{l}\text { Measure } \\
\text { variables }\end{array}$ & $\begin{array}{l}\text { Correlation } \\
\text { type }\end{array}$ & statistics & $\begin{array}{l}\text { Correlation } \\
\text { value }\end{array}$ & sig \\
\hline $\begin{array}{l}\text { social-economic status of students - } \\
\text { globalism }\end{array}$ & $\begin{array}{l}\text { Sequential- } \\
\text { sequential }\end{array}$ & Spearman & $r$ & 0.48 & 0.000 \\
\hline
\end{tabular}

Results of Table 16 shows that regarding the result of Spearmen correlation test $(\mathrm{r}=-0.48)$ and significance level $(\alpha=0.00)$, at $99 \%$ confidence level and error level below 0.05 , it is said that the correlation between the social-economic status of teachers and globalism is positive. In other words, any variation (increase or decrease) in one variable leads to the variation of the other. It means that the higher the social-economic status (i.e. education, job and income of students' parents), the higher the globalism of the students. Thus, H6 is confirmed.

Table 17. Results of correlation test for residence level and globalism

\begin{tabular}{llllll}
\hline variables & Measure of variables & Correlation type & statistics & Correlation value & Sig (p) \\
\hline residence level -globalism & Sequential- sequential & Pearson & $\mathrm{r}$ & 0.152 & 0.226 \\
\hline
\end{tabular}

Regarding the correlation value $(r=0.152)$ and significance level $(\alpha=0.226)$ in Table 17 , it is said that there is no significant correlation between residence level and globalism. Thus, H7 is rejected.

Table 18. Results of correlation test for using new media and globalism

\begin{tabular}{llllll}
\hline variables & Measure of variables & Correlation type & statistics & Correlation value & Sig (p) \\
\hline $\begin{array}{l}\text { Using new media- } \\
\text { globalism }\end{array}$ & Sequential- sequential & Spearman & $\mathrm{r}$ & 0.467 & 0.000 \\
\hline
\end{tabular}

Table 19. Summary of multiple regression test of teachers

\begin{tabular}{lllllll}
\hline $\begin{array}{l}\text { Dependent } \\
\text { variable }\end{array}$ & Independent variable & $\mathrm{R}$ & $\mathrm{R}^{2}$ & $\begin{array}{l}\text { Modified } \\
\mathrm{R}^{2}\end{array}$ & $\begin{array}{l}\text { Standard } \\
\text { error }\end{array}$ \\
\hline $\begin{array}{l}\text { Globalism of the } \\
\text { teachers }\end{array}$ & $\begin{array}{l}\text { Social-economic status, residence place, } \\
\text { residence level, using new media }\end{array}$ & 0.69 & 0.476 & 0.469 & 9.46 \\
\hline
\end{tabular}

Results of Table 18 shows that regarding the result of Spearman correlation test $(\mathrm{r}=0.467)$ and significance level $(\alpha=0.000)$, at $99 \%$ confidence level and error level below 0.01 , it is said that the correlation between using new media and globalism is positive. In other words, any variation (increase or decrease) in one variable leads to the variation of the other. It means that the higher the usage of new media, the higher the globalism of the students. Thus, H8 is confirmed.

Based on multiple regression results, multiple regression coefficient for the globalism of teachers is $\mathrm{r}=0.69$; thus, above variables are correlated with teachers' globalism as much as 0.69 . Also, these variables identify $46.9 \%$ of the total variance of dependent variable. 
Table 20. Standardized coefficient of $\beta$

\begin{tabular}{llllll}
\hline & \multicolumn{2}{l}{ Unstandardized coefficient } & Standardized coefficient & \multirow{2}{*}{ T } & \multirow{2}{*}{ sig } \\
Independent variables & $\beta$ & Estimation error & $\beta$ & 4.321 & 0.000 \\
\hline Fixed coefficient & 14.467 & 3.469 & - & 4.971 & 0.000 \\
Residence place & 2.461 & 0.379 & 0.209 & 5.122 & 0.000 \\
Social-economic status & 1.654 & 0.147 & 0.297 & 8.456 & 0.000 \\
Using new media & 0.872 & 0.091 & 0.689 & 5.131 & 0.098 \\
Residence level & -1.421 & 0.076 & 0.212 & & \\
\hline
\end{tabular}

Based on Table 20, most studied variables have significant effects on teachers' globalism. Using new media with $\beta$ of 0.689 has determination power more than other variables and affects globalism more than others. Then, social-economic status with beta of 0.297 , and residence place with beta of 0.209 have the next effects on globalism. Among these variables, residence level can't identify independent variable.

To identify the effect of each variable on the globalism of the students, multiple regression test was used whose results are shown in Table 21.

Table 21. Multiple regression test results for students

\begin{tabular}{lllllll}
\hline $\begin{array}{l}\text { Dependent } \\
\text { variable }\end{array}$ & Independent variable & $\mathrm{R}$ & $\mathrm{R}^{2}$ & $\begin{array}{l}\text { Modified } \\
\mathrm{R}^{2}\end{array}$ & $\begin{array}{l}\text { Standard } \\
\text { error }\end{array}$ \\
\hline $\begin{array}{l}\text { Students' } \\
\text { globalism }\end{array}$ & $\begin{array}{l}\text { Social-economic status, residence place, } \\
\text { residence level, using new media, gender }\end{array}$ & 0.781 & 0.609 & 0.598 & 10.42 \\
\hline
\end{tabular}

Based on multiple regression results, multiple regression coefficient for globalism of students is $\mathrm{r}=0.781$; thus, above variables are correlated with students' globalism as much as 0.609 . Also, these variables identify $59.8 \%$ of the total variance of dependent variable.

Table 22. Standardized coefficient of $\beta$

\begin{tabular}{llllll}
\hline \multirow{2}{*}{ Independent variables } & \multicolumn{2}{l}{ Unstandardized coefficient } & Standardized coefficient & \multirow{2}{*}{ T } & \multirow{2}{*}{ sig } \\
& $\beta$ & Estimation error & $\beta$ & 13.457 & 0.000 \\
Fixed coefficient & 18.341 & 3.334 & - & 4.121 & 0.000 \\
Residence place & 0.487 & 0.231 & 0.209 & 4.926 & 0.000 \\
Social-economic status & 0.321 & 0.092 & 0.302 & 9.493 & 0.000 \\
Using new media & 0.578 & 0.251 & 0.571 & 0.361 & 0.287 \\
Residence level & 0.089 & 0.097 & 0.054 & & \\
\hline
\end{tabular}

Based on Table 22, most variables have significant effects on students' globalism. Using new media with beta of 0.571 has more determination power than other variables and affects globalism more than others. Then, social-economic status with beta of 0.302 , and residence place with the beta of 0.209 have the next effects on globalism. Among these variables, residence level can't identify independent variable.

Comparing the results of multiple regression of teachers and students show that determination power of independent variables for students' globalism $\left(\mathrm{R} 2_{\mathrm{Adj}}=0.598\right)$ is higher than teachers $\left(\mathrm{R} 2_{\mathrm{Adj}}=0.469\right)$. In other words, independent variables of this study identify students' globalism more than teachers. From the other hand, comparing teachers and students regarding determination variable of globalism show that using new media has higher determination power than other variables and residence place has the lowest determination power of globalism in teachers and students.

\section{Conclusion}

This study aimed to compare the amount of high school teachers and students' globalism and identify effective factors in this regard and eight hypotheses were tested. Based on the hypotheses, attitudes towards new media such as satellite and Internet can affect teachers and students' globalism whose amount differs in both. Social and 
cultural structures of the society, social changes, social roles, role transfer, background job features and social context, economic and social status, mass media and etc. affect personal and social attitudes directly or indirectly. Results showed that variables of residence, economic and social status, and access to new media and usage of them affect high school teachers and students' globalism. Students have higher globalism than their teachers regarding cultural, social, political, and economic dimensions. Among all studied factors, new media had the maximum effect on teachers and students' globalism. The more the people use new media, the more their globalism tendencies increases. Globalism of the teachers and students in the city is higher than villagers. Social and economic status of teachers and students is positively correlated with their globalism amount. In other words, those with higher economic and social status have higher globalism. Residence of teachers and students (in city center, suburb, and town) don't affect their globalism. Results of this study have similarities and differences with other studies. Edrisi (2007) found that globalism has the maximum correlation with education level and is significantly correlated with personal and family features. The significance of this correlation is consistent with the findings of this study; but, based on this study; it doesn't have the maximum correlation with education level. Rather, globalism of teachers and students has maximum correlation with access to new media and using them. Lotfabadi and Noroozi (2004) showed that active attitude in pre-university students is higher while passive attitude towards globalism is lower. But, their result showed that students are more receptive to globalism and are pioneer in this regard compared with their teachers.

Pathologically, globalism difference of students with teachers leads to emotional, cultural, and ideological gap between teachers and students and can be a big cultural alarm for the society. Presence of two different generations in a process of educational mutual action leads to the feeling of needlessness and perfect independence, getting away from each other, bordering, contrast, boycott, hostility, norm-breaking, and disobeying rules. Although the statistics show higher globalism of students and the students don't have much interaction with their teachers, in practice, teachers are more globalist than the students but deny it. This creates a gap in the interactions of teachers and students. It seems that the present conditions necessitate creating a mechanism to fill the gap between the teachers and students. Thus, holding educational gatherings and seminaries for the teachers and teaching life skills for the students can provide a good area for identifying opportunities and positive and negative aspects of globalism. School textbooks can also teach the aspects and consequences of globalism and life requirements in the globalized context of today

\section{References}

Afroogh, E. (2008). We and globalization (1st ed.). Tehran, Sureh Mehr Publication.

Alport, G., \& Jones, A. (1992). Social psychology from the start till now. Translated by Maneshitoosi, M, Mashhad, Astan Gods Razavi Publication.

Bayat, A. (2007). Words culture, Ghom, Islamic Culture and Thought (3rd ed.).

Bokharaei, A. (2007). Sociology of social diversion in Iran (1st ed.). Tehran, Pejvak Jamee Publication.

Edrisi, A. (2007). Culture of globalism and identity-seeking of the youth (case study of students in Tehran University). Ph.D thesis of sociology, Islamic Azad University, Research and Science Branch. Giddens, A. (2007). Sociology, translated by Chavoshian. H, Tehran, Nashr Ney publication.

Giddens, A. (2009). Modernity and dignity, society and identity in new era. Translated by Movafagian, N, Tehran, Nashr Ney.

Golmohammadi, A. (2003). Globalism, culture, identity, Tehran, Nashr Ney (1st ed.).

Hejazi, M. (2003). Globalism and religion (article collection) (1st ed.). Tehran, Rozaneh Publication.

Inglehart, R. (1981). Post materialism in an environment of insecurity. American Political Science, 75. http://dx.doi.org/10.2307/1962290

Kicolt, K. J. (1988). Recent development in attitude and structure. Annual Review of Sociology, 14, 381-403. http://dx.doi.org/10.1146/annurev.so.14.080188.002121

Linson, J. (1999). Globalism and culture. Translated by Hakimi, M, Tehran, Cultural Research Bureau.

Lotfabadi, H. (2005). Examining the effect of high school and pre-university students 'attitudes in Iran towards globalism and its effect on their values, religious and national identity. Tehran, Research and Curriculum Planning of Education Department.

Lotfabadi, H., \& Noroozi, V. (2004). Investigating the ways of high school and pre-university students 'attitudes in Iran towards globalism and its effect on their values, religious and national identity, Tehran. Scientific 
Publication of Educational Innovations, 9, 88-119.

Oveisi, A., \& Bakhshi, H. (2003). Globalizm-articles and lectures; Globalism-congresses. Qazvin, Hadisrooz Publication.

Pishgahifard, Z. (2001). Journal of Arts Department, 63.

Sahabi, J., \& Aghabeigpoori, H. (n. d.). Investigating the effect of cultural aspect of globalism on ethnic identity. Tehran. Quarterly of National Studies, 11(1), 135-153.

Shahnooshi, M., \& Lalori, S. (2010). Effective factors in youth attitude towards globalism culture in Islamic Azad University of Shooshtar, Professional Quarterly of National Studies. 4th year, spring. Thomson, J. (2012). Media and modernity, translated by Ohadi, M, Tehran, Soroosh.

Vioyorka, M. (2002). Sociology challenges of contemporary area, translated by Farokh. Jose. Economic and Political Journal, 14, 149-150.

\section{Copyrights}

Copyright for this article is retained by the author(s), with first publication rights granted to the journal.

This is an open-access article distributed under the terms and conditions of the Creative Commons Attribution license (http://creativecommons.org/licenses/by/3.0/). 